\title{
Formal Thought Disorder and language impairment in schizophrenia
}

\author{
Alteração formal do pensamento e prejuízo da linguagem na esquizofrenia \\ Marcia Radanovic, Rafael T. de Sousa, Leandro L. Valiengo, Wagner Farid Gattaz, Orestes Vicente Forlenza
}

\begin{abstract}
Schizophrenia is a psychiatric illness in which disorders of thought content are a prominent feature. The disruption of normal flow of thought, or "Formal Thought Disorder" (FTD), has been traditionally assessed through the content and form of patients' speech, and speech abnormalities in schizophrenia were considered as a by-product of the disruption in conceptual structures and associative processes related to psychosis. This view has been changed due to increasing evidence that language per se is impaired in schizophrenia, especially its semantic, discursive, and pragmatic aspects. Schizophrenia is currently considered by some authors as a "language related human specific disease" or "logopathy", and the neuroanatomical and genetic correlates of the language impairment in these patients are under investigation. Such efforts may lead to a better understanding about the pathophysiology of this devastating mental disease. We present some current concepts related to FTD as opposed to primary neurolinguistic abnormalities in schizophrenia.
\end{abstract}

Key words: schizophrenia, thought disorder, language disorders, thinking, linguistic, psychotic disorders.

\section{RESUMO}

A esquizofrenia é uma doença psiquiátrica na qual as alterações do conteúdo do pensamento são uma característica marcante. A ruptura do fluxo normal de pensamentos, ou "Alteração Formal do Pensamento" (AFP) é acessada através da forma e conteúdo da fala do paciente. Alterações de fala e linguagem em esquizofrênicos eram consideradas como consequentes à ruptura de seus sistemas conceituais e processos associativos relacionados à psicose. Esta visão alterou-se pelo aumento nas evidências de comprometimento primário da linguagem na esquizofrenia, especialmente em seus aspectos semânticos, discursivos e pragmáticos. A esquizofrenia é atualmente considerada por alguns autores como uma "doença humana específica relacionada à linguagem", ou "logopatia". Os correlatos neuroanatômicos e genéticos do prejuízo linguístico nestes pacientes estão sendo investigados. Estes esforços podem levar à maior compreensão da fisiopatologia desta grave doença mental. Nesta revisão, apresentamos conceitos atuais sobre AFP e sua diferenciação das anormalidades linguísticas primárias na esquizofrenia.

Palavras-Chave: esquizofrenia, pensamento, transtornos da linguagem, pensamento, linguística, transtornos psicóticos.

Formal thought disorder (FTD) is a syndrome with several different symptoms, leading to thought, language and communication problems ${ }^{1}$, being a core feature in schizophrenia.

Eugen Bleuler, who named schizophrenia, regarded FTD as central for the conceptualization of the disorder ${ }^{2}$. Today FTD remains as one of the diagnostic criteria for schizophrenia according to the DSM-IV-TR ${ }^{3}$. Although FTD is listed as one of the five characteristic symptoms of the disorder, it has not been operationalized in the manual.

Since early FTD descriptions, there has been a debate on ascribing the symptom to the field of language or thought. Bleuler used the expression Beziehungslosigkeit (associative loosening), attributing the symptom to thought. In a different approach, Chaika ${ }^{4}$ recurred to the expression "speech disorder" to describe the symptom. She stated that only the language is appreciable, not the thought. Likewise, Andreasen argued that we can analyze only the speech, while thinking remains always somehow inaccessible ${ }^{5}$. When approaching FTD, Andreasen used the expression thought, language and communication (TLC), pointing to the construct complexity. Ultimately, the basis for FTD analysis is the verbal behavior, the speech of the patient.

Empirically, thought and language are not perfectly related. For instance, people can use language to hide or distort what they really think. Also, aphasic patients find it difficult to express in words what they are able to think.

In the last two decades the debate on the nature of FTD led to an increasing interest in the relation between 
FTD and primary language disturbances found in schizophrenia. Crow $^{6}$ postulated FTD could be derived from a lack of hemispheric asymmetry in language areas. This article reviews studies on FTD and its association with neurolinguistic abnormalities.

\section{FORMAL THOUGHT DISORDER SYMPTOMS}

FTD can be divided into abnormalities of amount and form of speech. Abnormalities concerning amount are poverty of speech (laconic speech) and pressure of speech, while disconnection symptoms relate to the abnormalities in the form $^{1,7-9}$. Disconnection encompasses distractible speech, loss of goal, derailment (loose associations), illogicality (non sequitur), and incoherence.

Besides this most usual description of FTD symptoms, other authors analyzed FTD in the perspective of communication failure ${ }^{10,11}$. FTD symptoms described by Gordinier and Docherty ${ }^{11}$ include inadequacy in language structure leading to confusing references (a word or phrase that can refer to at least two references), conceptual weakness associated with the use of ambiguous word meanings and vague expressions, and missing information references (citing something not known by the listener and not previously presented).

\section{FORMAL THOUGHT DISORDER MIGHT BE USEFUL IN THE DIFFERENTIAL DIAGNOSIS OF SCHIZOPHRENIA}

Bleuler assigned FTD a prominent place in diagnosing schizophrenia, leading many American psychiatrists to regard thought disorder as a sine qua non finding for this diagnosis $^{5}$. Over time, however, FTD has been shown to be associated with many other psychiatric conditions, especially bipolar mania ${ }^{12,13}$.

Although there are no FTD symptoms which are specific for any disorders, their evaluation might be useful in the differential diagnosis of schizophrenia/schizoaffective disorder and bipolar mania with psychosis (Table). Schizophrenia patients show a greater frequency of vague expressions in discourse than manic patients ${ }^{14}$, are more likely to construct ill-formed sentences ${ }^{12}$, and to present poverty of speech and its content ${ }^{13,15}$. In the follow-up, FTD tends to normalize in bipolar mania and to present little improvement in schizophrenia/schizoaffective disorder ${ }^{1}$.

In mania, FTD shows more combinations of confabulatory, incongruous, and mocking elements ${ }^{16}$. In turn, FTD in schizophrenia/schizoaffective disorder shows more disorganization, confusion and conceptual or ideational fluency, as well as the use of more peculiar words and phrases ${ }^{16,17}$.

\section{FORMAL THOUGHT DISORDER - NEUROLINGUISTICS PERSPECTIVE}

Many studies focused on speech abnormalities in schizophrenia, and they often do not distinguish what is understood as thought and/or language disorders and cognitive function. In other words, there is not a clear distinction between the content of mental representations stored in the brain, which are derived from innate programs and the progressive experience of interaction with the environment, and language itself, conceptualized as a symbol system that organizes information mentally and also as a behavior that allows interaction with other individuals. A major methodological difficulty arises from the fact that "thought disorders" shall be measured by the verbal output of the patient, making it extremely difficult to differentiate between the former and a primary language disorder. In fact, the terms "thought disorder" and "speech disorder" are often used interchangeably in psychiatric literature.

The first studies on language disorders in schizophrenia described the similarities between this disorder and aphasia, arguing that episodes of "intermittent aphasia" occurred in schizophrenia ${ }^{18}$. The speech of schizophrenics apparently shared some characteristics with fluent aphasia: increased fluency on spontaneous speech, paraphasias, impoverishment of content, and idiosyncrasies in the use of words. Comparative studies have also demonstrated similar performance between schizophrenics with language disorder and aphasia on tasks of language comprehension, naming and repetition, with abundant semantic paraphasias present in both cases. However, this approach was not sufficiently consistent across different studies ${ }^{19,20}$.

The finding that schizophrenia patients have cognitive decline in several areas obscured language impairment, which came to be regarded as secondary to an overall cognitive deficit, and not due to a primary problem in language processing. However, the idea remained that in schizophrenia there

Table. Formal thought disorder in schizophrenia and bipolar disorder.

\begin{tabular}{lll}
\hline Disorder & \multicolumn{1}{c}{ Most characteristic symptoms } & \multicolumn{1}{c}{ Follow-up } \\
Schizophrenia/ & $\begin{array}{l}\text { Disorganization, confusion and conceptual or } \\
\text { ideational fluency, and the use of odd words and } \\
\text { phrases. }\end{array}$ & $\begin{array}{l}\text { Confabulatory, incongruous and mocking } \\
\text { associations }\end{array}$ \\
Mania & Trend to normalization \\
\hline
\end{tabular}


are difficulties in semantic association and activation of lexical networks, and that these flaws would be responsible for symptoms such as bizarre content of speech, neologisms, and the classic symptom of "word salad".

In this sense, psycholinguistic studies have shown that schizophrenic patients show difficulties in semantically clustering similar exemplars in tasks of verbal fluency. Another phenomenon observed was an increase in object chaining at the end of sentences (associative intrusions), which could explain the deviations of discourse on the disorder. It is unclear how much these changes are due to hyperstimulation of semantic networks or the nature of attention deficits. Signs of a possible increase in stimulation of semantic networks were also demonstrated in studies of priming in schizophrenics who have been especially sensitive to semantic priming, as compared to phonological priming. Thus, schizophrenic patients seem to have a semantic facilitation, so that the stimulus spreads faster and reaches more distant points in the semantic network ${ }^{21-23}$.

This semantic facilitation could account for the symptom labeled as glossomania: when faced with a demand to produce a given word such as "bank" (a financial institution), the patient would be unable to inhibit the semantic associations with "bank" (the side of a river) and a flow of words related to the two meanings would be fired, being the individual unable to exercise adequate control over his production ${ }^{24}$.

Lexical access difficulties lead schizophrenic patients to an approximation conduct, which refers to the use of words that approximate the intended meaning (paraphasias), as "reflector" to "mirror", and in this approximation process the patient may even create non-existing words (neologisms) ${ }^{25}$.

Semantic difficulties are particularly important in schizophrenia in order to be treated as the essence of FTD; moreover, schizophrenia is perceived by some authors as a disorder of semiotics ${ }^{26,27}$.

Another finding is the difficulty in generating narratives based on pictures, with a high occurrence of irrelevant utterances, although without the naming difficulties exhibited, for instance, by aphasic patients ${ }^{28}$.

The aforementioned findings indicate the predominant involvement in the macrostructure of the discourse, leaving intact the most basic aspects of linguistic processing, such as naming, repetition, and comprehension of words. However, more recent psycholinguistic studies using formal language testing have repeatedly shown deficiencies in the primary processing at various linguistic levels.

Disorders of segmental phonological level are virtually nonexistent in schizophrenic patients. Even when producing neologisms, these patients follow the phonemic, syllabic and emphasis rules of their native language, so that the listener can be induced to think the fault lies in his own perception, rather than on the production of the patient ${ }^{27}$.

With respect to prosody, there are descriptions of the existence of production dysprosody (when the patient presents a monotonous speech, which is unable to reflect his emotional state) and of comprehension dysprosody (the inability to identify emotional aspects of the speech of others ${ }^{29,30}$.

Pure morphological deficits, such as errors in verb conjugation or in affixation and suffixation to generate derived words are also rare in schizophrenia. When these occur, they are not easily distinguishable from lexical access or syntax errors ${ }^{27}$.

Regarding syntax there is some degree of dysyntaxia, but not agrammatism. Schizophrenic patients tend to use more simplified phrases and less embedded sentences, showing greater repetition of words, fewer relative clauses, and the increase in syntactic complexity leads to semantic deviations. The grammatical impoverishment seems to be associated with negative symptoms and chronicity of the disease $\mathrm{e}^{31-33}$. Difficulties in the comprehension of syntax were also observed. However, it may be difficult to differentiate between the primary impairments in syntactic processing from those related to loss of memory, also described in schizophrenia, since changes in working memory may also interfere with the ability to comprehend more complex material. In fact, the interaction between memory deficits, attention and executive functions (supportive functions of language), also present in schizophrenia, may contribute to language impairments found in the disorder ${ }^{34,35}$. Rodriguez-Ferrera et al. ${ }^{36}$ suggest that the existing global intellectual impairment in schizophrenia is a determining factor for the bad performance in formal tests of language, also highlighting the difficulty of disregarding the thought disorder as an integral part of these difficulties, which leads to a cause-effect loop.

Losses in pragmatic aspects, or the contextual use of language, are most evident in patients with schizophrenia. They have great difficulty in maintaining the lexical cohesion of discourse, as well as the concatenation of speech segments around a certain theme, through the use of linguistic resources, such as conjunctions, pronouns, repetition, use of similar words, etc. Such handicaps, in turn, are closely related to the difficulty in establishing the reference of speech, or the subject being treated, which becomes based on lexical and prosodic features for the elaboration of the sentence chaining, and those with the preceding context. Moreover, they have difficulty in introducing new information (predicative speech $)^{34}$. This trait is particularly stable during the disorder, and seems to be related to FTD ${ }^{37}$. The coherence of the discourse is also greatly affected in schizophrenia, in a way that the discursive production seems to obey no predetermined "plan" to communicate any particular ideas ${ }^{12}$, but is rather formed by a succession of emissions not necessarily inter-related (or, as described above, through mechanisms related to phonological or semantic association).

Studies in pragmatics are closely inter-related to another cognitive skill that is greatly impaired in schizophrenia: the "Theory of Mind (ToM)", or the ability to attribute mental states to others and predict their behavior from these assignments. In some circumstances the distinction between 
purely pragmatic disorders and those involving a deficient ToM may be very difficult ${ }^{38}$.

Advances in the knowledge of language alterations and the recognition of their intimate correlation with thought disorders in schizophrenia has led the disease to be described as a "logopathy" ${ }^{\text {, }}$, or a "language related human specific disease". One of the most intriguing questions in this topic relates to traits that can be found in relatives of schizophrenic patients, such as grammatical oversimplification and deviant verbalizations present in non-schizophrenic family members of affected subjects ${ }^{40,41}$, suggesting a genetic association between language and schizophrenia. This association is widely supported by $\mathrm{Crow}^{42}$, who defends that the same genetic mutation that allowed the emergence of language made Homo sapiens vulnerable to failures in this system, and these failures may be clinically manifested as schizophrenia. Candidates for such schizophrenia vulnerability are the FOXP2 (which is linked to a familial language disorder and autism) and dysbindin 1 genes ${ }^{43,44}$.

\section{FORMAL THOUGHT DISORDER MAY BE A SCHIZOPHRENIA TRAIT MARKER}

FTD symptoms are not specific to schizophrenia patients, but rather are correlated to schizophrenia spectrum disorders ${ }^{45,46}$ and to a family history of schizophrenia ${ }^{47,48}$. Wahlberg $^{49}$ found that adoptees of parents with schizophrenia showed more FTD symptoms than adoptees of normal controls. Notably, Ott ${ }^{50}$ and Gooding ${ }^{48}$ found increased FTD symptoms previous to the development of psychosis. Docherty $^{37}$ showed that FTD symptoms (related to referential disturbances) were stable over time, independently of variances in clinical state, which reinforces that some FTD symptoms might reflect vulnerability to schizophrenia and may be schizophrenia trait markers.

\section{FORMAL THOUGHT DISORDER IS ASSOCIATED WITH STRUCTURAL AND FUNCTIONAL BRAIN CHANGES}

FTD in schizophrenia showed correlation with structural abnormalities in the left superior temporal gyrus
$(\mathrm{STG})^{51,52}$, the left planum temporale ${ }^{53,54}$ and the orbitofrontal cortex ${ }^{52,55}$. Also, studies using positron emission tomography ${ }^{56}$ and functional magnetic resonance imaging ${ }^{57,58}$ correlate left STG with FTD, being thus consistent with structural findings.

\section{TRENDS AND PERSPECTIVES IN THE STUDY OF FTD AND LANGUAGE DISORDERS IN SCHIZOPHRENIA}

One possible area of research is the evaluation of FTD and its relation with the outcome of the first psychotic episode. Another area that deserves attention is the relationship of FTD with functional and structural brain changes. The interdependence with the neurotransmitters present in the disease is also a field for research.

Regarding the primary changes of language in schizophrenia, some issues still deserve further investigation, since most of the work to date has focused on semantics and discourse. Other linguistic aspects such as phonology, syntax, prosody, and pragmatic studies still need to be investigated with better methodology, taking into account the recent advances in psychological and neurolinguistics theories and the most recent methods of functional neuroimaging. Studies correlating linguistic and biological dysfunctions (such as genetics and heredity) may also bring valuable contributions to the understanding of the relationship between linguistic processing and abnormal psychopathological processes in schizophrenia and other psychiatric illnesses. Language is a cognitive function that differentiates us as a species, and a deep understanding of its processes is essential. Language is important as a structuring element of thought and sense of self and world, as mediator of reasoning and communication and also for sharing experiences with other human beings. It has a potential to cause disruption of the harmonious functioning of the nervous system as well as the ability to assist in the remodeling of this operation, a factor exploited on a large scale in the various forms of "talking cure".

Finally, it is worth noting that thought and language, although closely interrelated, are not isomorphic, and that FTD and language impairments are supposed to be studied as separate entities that coexist in schizophrenia.

\section{References}

1. Andreasen NC, Grove WM. Thought, language, and communication in schizophrenia: diagnosis and prognosis. Schizophr Bull 1986;12:348-359.

2. Bleuler Dementia Praecox: Or the Group of Schizophrenias. New York: International Universities Press; 1911.

3. American Psychiatric Association: Diagnostic and Statistical Manual of Mental Disorders. $4^{\text {th }}$ ed, Text Revision. Washington, DC: American Psychiatric Association; 2000.

\footnotetext{
4. Chaika E. Thought disorder or speech disorder in schizophrenia? Schizophr Bull 1982;8:587-594.

5. Andreasen NC. Thought, language, and communication disorders. I. Clinical assessment, definition of terms, and assessment of their reliability. Arch Gen Psychiatry 1979;36:1315-1321.

6. Crow TJ. Schizophrenia as failure of hemispheric dominance for language. Trends Neurosci 1997;20:339-343.
} 
7. Cuesta MJ, Peralta V. Thought disorder in schizophrenia. Testing models through confirmatory factor analysis. Eur Arch Psychiatry Clin Neurosci 1999;249:55-61.

8. Berenbaum H, Oltmanns TF, Gottesman II. Formal thought disorder in schizophrenics and their twins. J Abnorm Psychol 1985;94: 3-16.

9. Harvey PD, Lenzenweger MF, Keefe RS, Pogge DL, Serper MR, Mohs RC. Empirical assessment of the factorial structure of clinical symptoms in schizophrenic patients: formal thought disorder. Psychiatry Res 1992;44:141-151.

10. Barrera A, McKenna PJ, Berrios GE. Two new scales of formal thought disorder in schizophrenia. Psychiatry Res 2008;157:225-234.

11. Gordinier SW, Docherty NM. Factor analysis of the Communication Disturbances Index. Psychiatry Res 2001;101: 55-62.

12. Hoffman RE, Stopek S, Andreasen NC. A comparative study of manic vs. schizophrenic speech disorganization. Arch Gen Psychiatry 1986;43:831-838.

13. Andreasen NC. Thought, language, and communication disorders. II. Diagnostic significance. Arch Gen Psychiatry 1979;36:1325-1330.

14. Docherty NM, DeRosa M, Andreasen NC.Communication disturbances in schizophrenia and mania. Arch Gen Psychiatry 1996;53:358-364.

15. Harvey PD, Serper MR. Linguistic and cognitive failures in schizophrenia. A multivariate analysis. J Nerv Ment Dis 1990;178: 487-493.

16. Solovay MR, Shenton ME, Holzman PS. Comparative studies of thought disorders. I. Mania and schizophrenia. Arch Gen Psychiatry 1987;44:13-20.

17. Shenton ME, Solovay MR, Holzman P. Comparative studies of thought disorders. II. Schizoaffective disorder. Arch Gen Psychiatry 1987;44:21-30.

18. Chaika E. A linguist looks at "schizophrenic" language. Brain Lang 1974;1:257-276.

19. Gerson SN, Benson F, Frazier SH. Diagnosis: schizophrenia versus posterior aphasia. Am J Psychiatry 1977;134:966-969.

20. Faber R, Abrams R, Taylor MA, Kasprison A, Morris C, Weisz R. A comparison of schizophrenic patients with formal thought disorder and neurologically impaired patients with aphasia. Am J Psychiatry 1983;140:1348-1351.

21. Aloia MS, Gourovitch ML, Weinberger DR, GoldbergTE. An investigation of semantic space in patients with schizophrenia. J Int Neuropsychol Soc 1996;2:267-273.

22. Manschreck TC, Maher B, Celada MT, Schneyer M, Fernandez R. Object chaining and thought disorder in schizophrenic speech. Psychol Med 1991;21:443-446.

23. Spitzer M, Weisker I, Winter M, Maier S, Hermle L, Maher BA. Semantic and phonological priming in schizophrenia. J Abnorm Psychol 1994;103:485-494

24. Cohen BD, Nachmani G, Rosenberg S. Referent communication disturbances in acute schizophrenia.J Abnorm Psychol 1974;83:1-13.

25. Allen HA, Liddle PF, Frith CD. Negative features, retrieval processes and verbal fluency in schizophrenia. $\mathrm{Br} J$ Psychiatry 1993;163: 769-775.

26. Oh TM, McCarthy RA, McKenna PJ. Is there a schizophasia? A study applying the single case approach to formal thought disorder in schizophrenia. Neurocase 2002;8:233-244.

27. Covington MA, He C, Brown C, et al. Schizophrenia and the structure of language: the linguist's view. Schizophr Res 2005;77:85-98.

28. Goldfarb R, Stocker B, Eisenson J, DeSanti S. Communicative responsibility and semantic task in aphasia and "schizophasia". Percept Mot Skills 1994;79:1027-1039.

29. Alpert M, Rosen A, Welkowitz J, Sobin C, Borod JC. Vocal acoustic correlates of flat affect in schizophrenia. Similarity to Parkinson's disease and right hemisphere disease and contrast with depression. Br J Psychiatry Suppl 1989;154:51-56.
30. Rieber RW, Vetter $\mathrm{H}$. The problem of language and thought in schizophrenia: a review. J Psycholinguist Res 1994;23:149-195.

31. Morice R, McNicol D. Language changes in schizophrenia: a limited replication. Schizophr Bull 1986;12:239-251.

32. Thomas P, King K, Fraser WI, Kendell RE. Linguistic performance in schizophrenia: a comparison of acute and chronic patients. $\mathrm{Br} J$ Psychiatry 1990;156:204-210

33. King K, Fraser WI, Thomas P, Kendell RE. Re-examination of the language of psychotic subjects. Br J Psychiatry 1990;156:211-215.

34. Tracy J, Glosser G, DellaPietra L. A cognitive/linguistic model of single word production abnormalities in schizophrenia. Data from two case reports. Brain Cogn 1996;30:311-315.

35. Daffner KR, Searl MM. The dysexecutive syndromes. Handb Clin Neurol 2008;88:249-267.

36. Rodriguez-Ferrera S, McCarthy RA, McKenna PJ. Language in schizophrenia and its relationship to formal thought disorder. Psycho Med 2011;31:197-205.

37. Docherty NM, Cohen AS, Nienow TM, Dinzeo TJ, Dangelmaier RE. Stability of formal thought disorder and referential communication disturbances in schizophrenia. J Abnorm Psychol 2003;112: 469-475.

38. Mazza M, Di Michele V, Pollice R, Casacchia M, Roncone R. Pragmatic language and theory of mind deficits in people with schizophrenia and their relatives. Psychopathology 2008;41: 254-263.

39. Zegers OD. Schizophrenia, language and evolution (or the schizophrenias as logopathies). Actas Esp Psiquiatr 2010;38:1-7.

40. DeLisi LE. Speech disorder in schizophrenia: review of the literature and exploration of its relation to the uniquely human capacity for language. Schizophr Bull 2001;27:481-496.

41. Levy DL, Coleman MJ, Sung H, et al. The Genetic Basis of Thought Disorder and Language and Communication Disturbances in Schizophrenia. J Neurolinguistics 2010;23:176.

42. Crow TJ. The torque defines the four quadrants of the human language circuit and the nuclear symptoms of schizophrenia identify their component functions. In: Stemmer B, Whitaker HA (Eds.) Handbook of the Neuroscience of Language. San Diego, CA: Academic Press; 2008. p. 299-307.

43. Markov V, Krug A, Krach S, et al. Genetic variation in schizophreniarisk-gene dysbindin 1 modulates brain activation in anterior cingulate cortex and right temporal gyrus during language production in healthy individuals. Neuroimage 2009;47:2016-2022.

44. Tolosa A, Sanjuán J, Dagnall AM, Moltó MD, Herrero N, de Frutos R. FOXP2 gene and language impairment in schizophrenia: association and epigenetic studies. BMC Med Genet 2010;11:114.

45. Gooding DC, Tallent KA, Hegyi JV. Cognitive slippage in schizotypic individuals. J Nerv Ment Dis 2001;189:750-756.

46. Vaever MS, Licht DM, Møller L, et al. Thinking within the spectrum: schizophrenic thought disorder in six Danish pedigrees. Schizophr Res 2005;72:137-149.

47. Kinney DK, Holzman PS, Jacobsen B, et al. Thought disorder in schizophrenic and control adoptees and their relatives. Arch Gen Psychiatry 1997;54:475-479.

48. Gooding DC, Coleman MJ, Roberts SA, Shenton ME, Levy DL, Erlenmeyer-Kimling L. Thought disorder in offspring of schizophrenic parents: findings from the New York High-Risk Project. Schizophr Bull 2012;38:263-271.

49. Wahlberg K-E, Wynne LC, Oja H, et al. Thought disorder index of Finnish adoptees and communication deviance of their adoptive parents. Psychol Med 2000;30:127-136.

50. Ott SL, Roberts S, Rock D, Allen J, Erlenmeyer-Kimling L. Positive and negative thought disorder and psychopathology in childhood among subjects with adulthood schizophrenia. Schizophr Res 2002;58: 231-239. 
51. Subotnik KL, Bartzokis G, Green MF, Nuechterlein KH. Neuroanatomical correlates of formal thought disorder in schizophrenia. Cogn Neuropsychiatry 2003;8:81-88.

52. Horn H, Federspiel A, Wirth M, et al. Gray matter volume differences specific to formal thought disorder in schizophrenia. Psychiatry Res 2010;182:183-186

53. Petty RG, Barta PE, Pearlson GD, et al. Reversal of asymmetry of the planum temporale in schizophrenia. Am J Psychiatry 1995;152:715-721.

54. Barta PE, Pearlson GD, Brill LB 2nd, et al. Planum temporale asymmetry reversal in schizophrenia: replication and relationship to gray matter abnormalities. Am J Psychiatry 1997;154:661-667.
55. Nakamura M, Nestor PG, Levitt JJ, et al. Orbitofrontal volume deficit in schizophrenia and thought disorder. Brain 2008;131:180-195.

56. McGuire PK, Quested DJ, Spence SA, Murray RM, Frith CD, Liddle PF. Pathophysiology of 'positive' thought disorder in schizophrenia. Br J Psychiatry 1998;173:231-235.

57. Weinstein S, Werker JF, Vouloumanos A, Woodward TS, Ngan ET. Do you hear what I hear? Neural correlates of thought disorder during listening to speech in schizophrenia. Schizophr Res 2006;86:130-137.

58. Horn H, Federspiel A, Wirth M, et al. Structural and metabolic changes in language areas linked to formal thought disorder. Br J Psychiatry 2009;194:130-138. 